\title{
ЕКОЛОГІЗАЦІЯ ПОДАТКОВОЇ ПОЛІТИКИ ЯК ВАЖЛИВИЙ НАПРЯМ РОЗВИТКУ КРАЇНИ
}

\section{GREENING OF THE TAX POLICY AS AN IMPORTANT DIRECTION OF THE COUNTRY'S DEVELOPMENT}

\author{
Мартинюк Ірина Василівна \\ кандидат економічних наук, доцент, \\ Одеський національний економічний університет \\ ORCID: http://orcid.org/0000-0002-6361-4232
}

\author{
Martyniuk Iryna \\ Odessa national economic university
}

\begin{abstract}
У статті розглянуто екологізацію податкової політики України як важливий напрям розвитку економіки. Проведено комплексний аналіз загального негативного навантаження забруднюючими речовинами та відходами на навколишнє природне середовище в Україні. Запропоновано методику розрахунку екологічної ефективності податкової політики. Визначено умови досягнення екологічної ефрективності податкової політики. Проведено аналіз показників екологічної ефективності податкової політики України за 2010-2019 рр. Здійснено оцінювання екологічної ефективності податкової політики України за заданими нами умовами за період 2010-2019 рр. Виявлено недоліки, які потребують невідкладного вирішення з метою підвищення екологічної ефрективності податкової політики. Запропоновано кроки щодо подальшої екологізації податкової політики України.
\end{abstract}

Ключові слова: екологізація, зелена економіка, податкова політика, екологічна ефективність, утилізаційний збір.

В статье рассмотрен процесс экологизации налоговой политики Украины как важное направление развития экономики. Проведен комплексный анализ общей негативной нагрузки загрязняющими веществами и отходами на окружающую среду в Украине. Предложена методика расчета экологической эффективности налоговой политики. Определены условия достижения экологической эффективности налоговой политики. Проведен комплексный анализ показателей экологической эфффективности налоговой политики Украины. Осуществлено оценивание экологической эфффективности налоговой политики Украины за заданными нами условиями за период 2010-2019 гг. Выявлены недостатки, требующие безотлагательного решения с целью повышения экологической эсрсективности налоговой политики. Предложено шаги по дальнейшей экологизации налоговой политики Украины.

Ключевые слова: экологизация, зеленая экономика, налоговая политика, экологическая эффективность, утилизационный сбор.

The article is devoted to the greening of Ukraine's tax policy as an important direction of economic development. The essence of the concepts "greening of the economy", "green economy" and "environmental efficiency index" is defined. A comprehensive analysis of the overall negative load of pollutants and waste on the environment in Ukraine was conducted. The priority directions of greening of the country's economy are determined. The essence of greening of tax policy is determined. The method of calculation of ecological efficiency of tax policy is offered, which takes into account the following aspects: increase in budget revenues and trust funds from natural resource payments; reduction of ecologically dangerous activity; preservation and reproduction of natural resource potential. The proposed methodology provides for the introduction of an additional indicator in the system of indicators for assessing the environmental performance of tax policy, which reflects the share of recycled waste in the total amount of waste generated. The conditions for achieving environmental efficiency of tax policy are determined. The analysis of indicators of ecological efficiency of tax policy of Ukraine for 2010-2019 is carried out. The estimation of ecological efficiency of tax policy of Ukraine under the conditions set by us for the period of 2010-2019 is carried out. As a result of the analysis, it was found that in any year of the study period, tax policy was not environmentally efficient. For most of the years, the tax policy was fiscally oriented and only in 2012 and 2015-2016 the tax policy was environmentally efficient according to some of the established criteria. Shortcomings have been identified that need to be addressed immediately to improve the environmental performance of tax policy. Steps for further greening of Ukraine's tax policy are proposed: development and implementation of recycling fees, further implementation of changes in the field of environmental taxation within the framework of eco-tax reform, increase funding for environmental protection and reproduction of natural resources and others.

Keywords: greening, green economy, tax policy, environmental efficiency, recycling fee. 
Постановка проблеми. Реалії сьогодення свідчать, що сталий розвиток країни неможливо уявити без урахування економічної, соціальної та екологічної складових. В сучасних умовах екологічні питання стають все більше актуальними, а терміни «зелена» економіка, «екологізація» економіки входять у повсякденне використання.

Екологізація економіки - це важливий напрям та модель розвитку економіки, який спрямований на усунення еколого-економічних протирічь і забезпечення гармонійного поєднання середовища життєдіяльності людини і якості навколишнього середовища [1].

Процес екологізації економіки спрямований на досягнення «зеленої» економіки, яка повинна: підвищити обізнаність про реальне екологічне, енергетичне та соціально-економічне становище світу, виявивши ідеологічні варіанти для кращого розуміння дилеми «економічне зростання та захист довкілля»; знайти оптимальні шляхи та більш ефективні інструменти для вирішення проблем, з якими стикнулося суспільство [2, с. 9].

Досягнення «зеленої» економіки відбувається через поступову екологізацію усіх сфрер життєдіяльності людини. Процес екологізації стає пріоритетним напрямом розвитку держави.

Аналіз останніх досліджень і публікацій. Проблеми екологізації економіки взагалі, та податкової політики зокрема, є об'єктом дослідження багатьох зарубіжних та вітчизняних науковців, серед яких: Веклич О.,
Данилишина Б., Джонсон Л., Крутякова В., Маркевич К., Маслюківська О., Патюелія Р., Хсу А. та інші. Але наявність багатьох еколого-економічних проблем, серед яких, значний обсяг викидів забруднюючих речовин у навколишнє природне середовище, неесективна політика держави щодо поводження з відходами та діюча система екологічного оподаткування в країні, обумовлюють необхідність подальших наукових досліджень та розробок з метою поглиблення екологізації податкової політики країни.

Формулювання цілей статті. Метою дослідження $€$ оцінювання сучасного стану екологізації податкової політики та пошук можливих шляхів її підвищення.

Виклад основного матеріалу дослідження. Для України процес екологізації економіки $€$ особливо актуальним, оскільки, незважаючи на позитивну динаміку щодо зменшення обсягів викидів забруднюючих речовин (табл. 1) та розміщених відходів (рис. 1), Україна посідає 60 місце серед 180 країн світу за індексом екологічної ефрективності (Environmental Performance Index). Індекс екологічної ефрективності - це метод кількісної оцінки та порівняльного аналізу показників екологічної політики держав світу. Індекс розраховується раз на два роки та передбачає дослідження двох груп показників: життєздатність екосистеми (управління природними ресурсами) та екологічне здоров'я, що оцінює вплив довкілля на здоров'я людини [3].

Таблиця 1

Динаміка викидів забруднюючих речовин у навколишнє природне середовище в Україні, 2010-2019 рр. [4]

\begin{tabular}{|c|c|c|c|c|c|c|c|c|}
\hline \multirow{4}{*}{ Роки } & \multicolumn{8}{|c|}{$\begin{array}{c}\text { Приріст (збиток) викидів забруднюючих речовин } \\
\text { у порівнянні } 3 \text { попереднім роком: }\end{array}$} \\
\hline & \multirow{2}{*}{\multicolumn{2}{|c|}{$\begin{array}{c}\text { усього (окрім } \\
\text { діоксиду вуглецю) }\end{array}$}} & \multicolumn{4}{|c|}{ у тому числі: } & \multirow{2}{*}{\multicolumn{2}{|c|}{ діоксиду вуглецю }} \\
\hline & & & \multicolumn{2}{|c|}{$\begin{array}{c}\text { стаціонарними } \\
\text { джерелами } \\
\text { забруднення }\end{array}$} & \multicolumn{2}{|c|}{$\begin{array}{c}\text { пересувними } \\
\text { джерелами } \\
\text { забруднення }\end{array}$} & & \\
\hline & $\begin{array}{l}\text { тис. } \\
\text { тонн }\end{array}$ & $\%$ & $\begin{array}{l}\text { тис. } \\
\text { тонн }\end{array}$ & $\%$ & $\begin{array}{l}\text { тис. } \\
\text { тонн }\end{array}$ & $\%$ & $\begin{array}{l}\text { млн. } \\
\text { тонн }\end{array}$ & $\%$ \\
\hline 2010 & 433,3 & 6,73 & 215,7 & 5,29 & 32,4 & 1,27 & 13 & 7,02 \\
\hline 2011 & 237,1 & 3,45 & 280,2 & 6,52 & $-43,1$ & $-1,67$ & 37,8 & 19,07 \\
\hline 2012 & $-60,2$ & -14 & $-43,3$ & $-0,95$ & $-16,9$ & $-0,67$ & -4 & $-1,69$ \\
\hline 2013 & $-101,3$ & $-1,49$ & $-40,2$ & $-0,93$ & $-61,1$ & $-2,46$ & $-1,3$ & $-0,56$ \\
\hline 2014 & $-1533,2$ & $-22,81$ & $-1104,7$ & $-25,72$ & $-428,5$ & $-17,67$ & $-49,8$ & $-21,58$ \\
\hline 2015 & $-824,9$ & $-15,43$ & $-492,6$ & $-14,70$ & $-332,3$ & $-16,65$ & $-32,7$ & $-16,80$ \\
\hline 2016 & $-1443,2$ & $-31,92$ & 220,7 & 7,72 & - & - & $-11,4$ & $-7,04$ \\
\hline 2017 & -456 & $-9,73$ & $-493,2$ & $-16,02$ & 37,2 & 2,31 & $-26,4$ & $-17,53$ \\
\hline 2018 & $-109,4$ & $-2,59$ & $-76,6$ & $-2,96$ & $-32,8$ & $-1,99$ & 2,2 & 1,77 \\
\hline 2019 & $-2,2$ & $-0,05$ & $-48,8$ & $-1,95$ & 46,6 & 2,89 & $-5,1$ & $-4,03$ \\
\hline
\end{tabular}


Дані табл. 1 свідчать, що протягом останніх восьми років відбувається зменшення викидів забруднюючих речовин у навколишнє природне середовище в середньому на $12,25 \%$, що $€$ наслідком поступової екологізації економіки держави, серед яких: запровадження змін у податковому та бюджетному законодавстві, у тому числі у характері використання надходжень від екологічного податку, а саме спрямування їх на фрінансове забезпечення цільових проектів екологічної модернізації підприємств. Варто також відмітити, що суттєве зменшення викидів у 2014-2019 рр. порівняно з 2010-2013 рр. обумовлено, нажаль, неврахуванням тимчасово окупованих територій.

Комплексний аналіз загального негативного навантаження забруднюючими речовинами та відходами на навколишнє природне середовище наведено на рис. 1 завдяки розрахунку та аналізу інтегрованого показника (1).

$\mathrm{E}_{\mathrm{ec} 1}=\left(\mathrm{B}_{\text {зрi }}-\mathrm{B}_{\text {зр (i-1) }}\right): \mathrm{B}_{\text {зр (i-1) }}+\left(\mathrm{Y}_{\mathrm{Bi}}-\mathrm{Y}_{\text {в (i-1) }}\right): \mathrm{Y}_{\text {в (i-1) }}(1)$

де $\mathrm{E}_{\text {ес1 }}$ - інтегрований показник, в умовних тонах;

$\mathrm{B}_{\text {зрі(i-1) }}$ - обсяги викидів забруднюючих речовин у поточному і-тому році (попередньому році), в умовних тонах;

$\mathrm{y}_{\text {ві(-1) }}$ - кількість утворених відходів у поточному і-тому році (попередньому році), в умовних тонах.

Протягом останніх років досліджуваного періоду відбувається зменшення негативного тиску на навколишнє природне середовище, виключенням $€ 2017$ р. У той же час, обсяги викидів забруднюючих речовин та розміщених відходів в Україні значно перевищують аналогічні показники розвинених країн. Так обсяги викидів діоксиду вуглецю в Україні перевищують викиди даної речовини у Швеції у 2,83 рази (станом на 2018 р.), а у Норвегії у 2,5 разів (станом на 2018 р.).

Наявність екологічних проблем потребує подальшої екологізації економіки держави, пріоритетними напрямами якої $€$ :

1. Забезпечення створення правової бази щодо становлення «зеленої» економіки, «зеленого» фрінансування в Україні.

2. Підвищення та заохочення ресурсозбереження, енергозбереження та зменшення негативного впливу на навколишнє природне середовище.

3. Забезпечення розробки екологічних програм.

4. Розробка та впровадження технологій щодо переробки та утилізації відходів.

5. Подальші зміни у сфрері екологічного оподаткування в межах екоподаткової ресоорми [2].

Усі пріоритетні напрями стосуються не лише економіки, але й податкової політики, екологізація якої допоможе вирішити ряд екологічних та соціально-економічних проблем.

Екологізація податкової політики, на наш погляд, передбачає побудову такої моделі податкової системи, що забезпечує розвиток суб'єктів господарювання, який спонукає їх до запровадження екологічно чистих та ресурсозберігаючих технологій з одночасною сплатою екологічних платежів, достатніх для фрінансування заходів 3 охорони та відтворення природно-ресурсного потенціалу.

Оцінювання рівня екологізації податкової політики, на наш погляд, можливо здійснити за рахунок аналізу системи показників, розроблених для дослідження екологічної ефек-

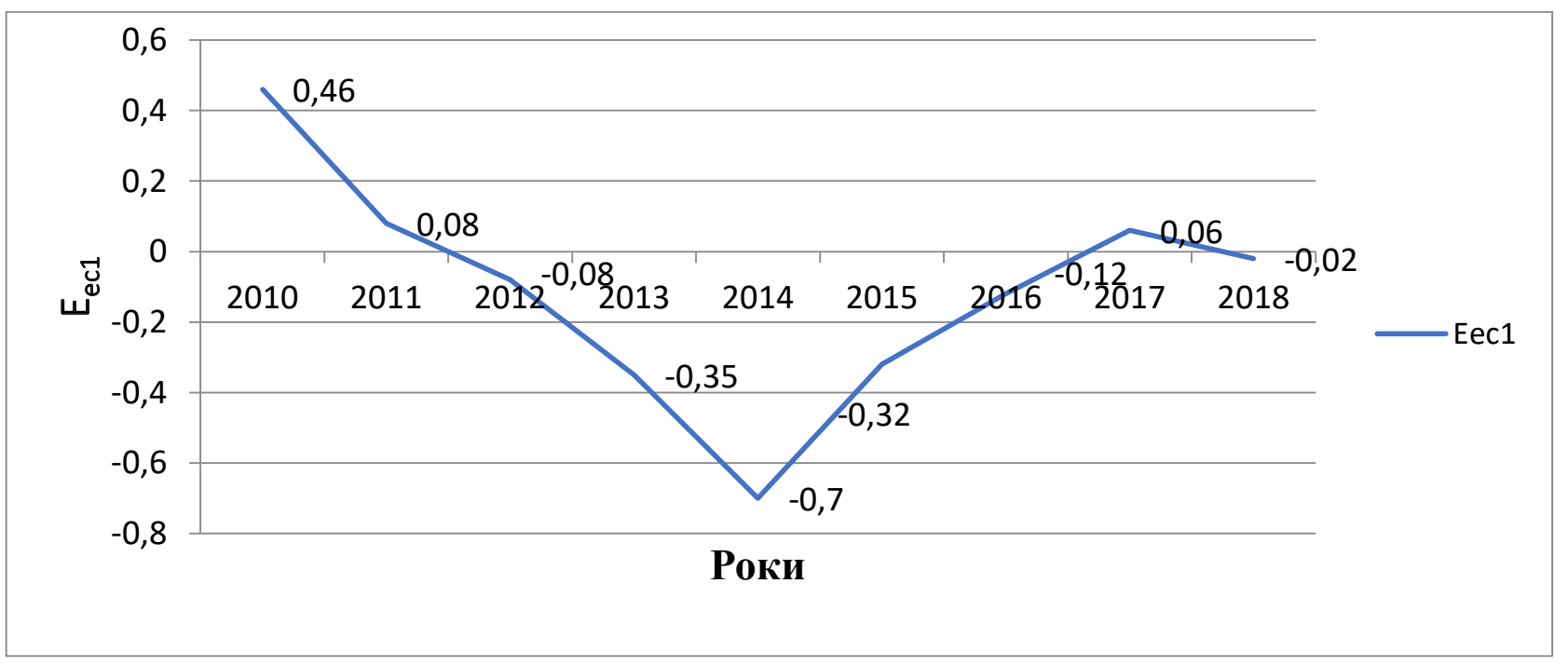

Рис. 1. Динаміка інтегрованого показника в Україні, 2010-2018 рр. [4] 
тивності податкової політики країни. Саме комплексний аналіз екологічної ефективності податкової політики країни забезпечить проведення ґрунтовного дослідження усіх складових екологічного оподаткування.

Проведене дослідження методик розрахунку екологічної ефеективності податкової політики надало змогу розробити та запропо- нувати для оцінки ефрективності методику, яка враховує наступні аспекти: збільшення надходжень до бюджету та цільових срондів від природно-ресурсних платежів; зменшення екологічно небезпечної діяльності; збереження та відтворення природно-ресурсного потенціалу.

Врахування вищезазначених аспектів відображено у запропонованій системі показників:

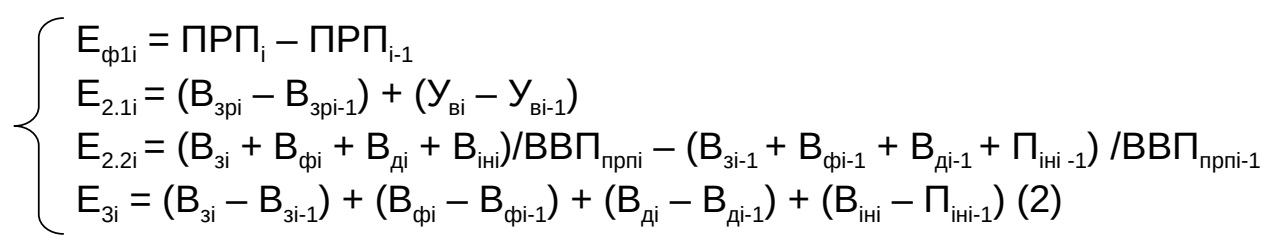

де $\mathrm{E}_{\text {ф1і }}$ - фріскальний ефект податкової політики у сорері використання природно-ресурсного потенціалу і-того року;

ПРП платежів в і-тому році (попередньому році);

$\mathrm{E}_{2.1 \mathrm{i}}$ - показник, що відображає зменшення обсягів викидів забруднюючих речовин (у тому числі діоксиду вуглецю) та обсягів утворених відходів;

$\mathrm{B}_{\text {зрі (зрі-1) }}$ - обсяги викидів забруднюючих речовин (у тому числі діоксиду вуглецю) в і-тому році (попередньому році);

$\mathrm{y}_{\text {ві (ві-1) }}$ - обсяги утворених відходів в і-тому році (попередньому році);

$\mathrm{E}_{2.2 i}$ - показник, що відображає динаміку екологічної безпеки країни з урахуванням лише ВВП, що створюється у галузях, які впливають на стан природно-ресурсного потенціалу (сільське господарство, добувна промисловість, переробна промисловість, виробництво та розподіл електроенергії, газу та води, будівництво, ремонт автомобілів, діяльність транспорту та зв'язку);

$\mathrm{B}_{\text {зі (зі-1) }}$ - витрати на запобігання та ліквідацію забруднення навколишнього природного середовища в і-тому році (попередньому році);

$\mathrm{B}_{\text {фi (कi-1) }}$ - витрати на збереження природнозаповідного фронду в і-тому році (попередньому році);

$\mathrm{B}_{\text {ді (ді-1) }}$ - витрати на дослідження та розробки у сорері охорони навколишнього природного середовища в і-тому році (попередньому році);

$\mathrm{B}_{\text {іні (iн-1) }}$ - витрати на іншу діяльність у сфрері охорони навколишнього природного середовища в і-тому році (попередньому році);

ВВП прпі (прпі-1) - ВВП, що створюється у галузях, які впливають на стан природно-ресурсного потенціалу (сільське господарство, добувна промисловість, переробна промисловість, виробництво та розподіл електроенергії, газу та води, будівництво, ремонт автомобілів, діяльність транспорту та зв'язку); де $\mathrm{E}_{3 і}$ - показник, що відображає динаміку здійснених витрат на охорону навколишнього природного середовища.

Запропонована методика дійсно надає змогу здійснити детальний аналіз екологічної есрективності податкової політики, що наводився нами у різноманітних публікаціях.

Але, варто зазначити, що останнім часом все більше уваги привертається до екологічних проблем, пов'язаних з утворенням та накопиченням відходів. Концепція циркулярної економіки, яка передбачає ефрективне використання природних ресурсів та зменшення відходів за рахунок їх переробки, стає все більше актуальною та відомою у світі. За даними Світового банку Україна входить у десятку країн за найбільшим обсягом утвореного сміття на одну людину. У той час, як обсяг утилізованих відходів у загальному обсязі утворених відходів незначний (рис. 2).

Отже, на наш погляд, з метою поглиблення дослідження екологічної ефективності податкової політики та виявлення можливих шляхів ії підвищення, необхідно:

- здійснити глибокий аналіз поведінки суб'єктів господарювання по відношенню до утворених відходів;

- знайти нові джерела фрінансування заходів з утилізації утворених відходів.

У зв'язку з цим, ми пропонуємо введення додаткового показника у систему показників оцінки екологічної ефективності податкової політики, який відображає питому вагу утилізованих відходів у загальному обсязі утворених відходів. Даний показник повинен мати динаміку до збільшення 3 кожним роком та спрямовуватися до одиниці:

$$
\mathrm{E}_{2.3 \mathrm{i}}=\mathrm{YT}_{\mathrm{Bi}} / \mathrm{Y}_{\mathrm{Bi}}-\mathrm{YT}_{\mathrm{Bi}-1} / \mathrm{Y}_{\mathrm{Bi}-1,}
$$

де $\mathrm{E}_{2.3 \mathrm{i}}$ - показник, що відображає динаміку питомої ваги утилізованих відходів у загальній кількості утворених відходів;

$\mathrm{YT}_{\text {ві (ві-1) }}$ обсяги утилізованих відходів в i-тому році (попередньому році). 


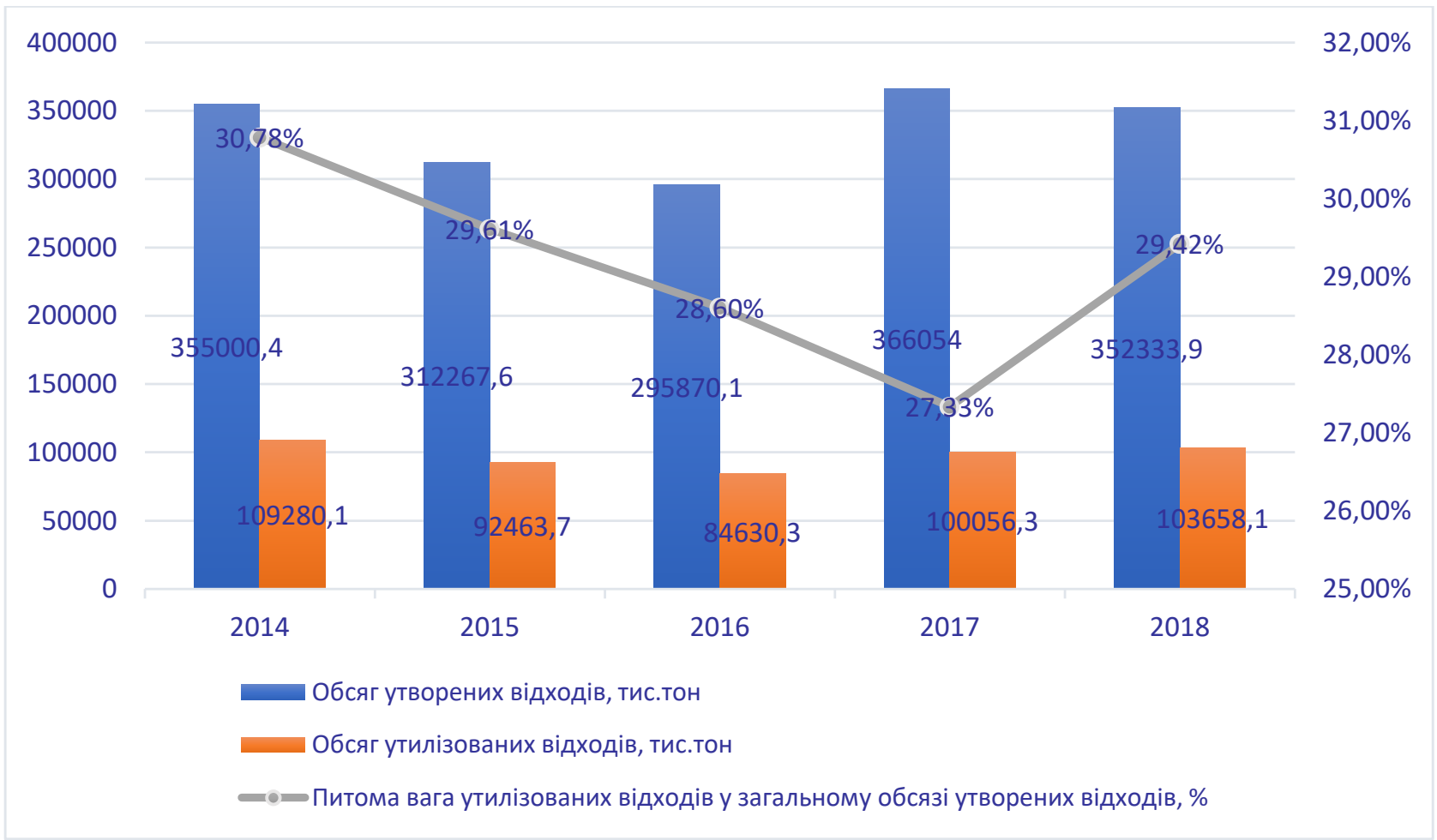

Рис. 2. Динаміка утворених та утилізованих відходів в Україні, 2014-2018 рр. [4]

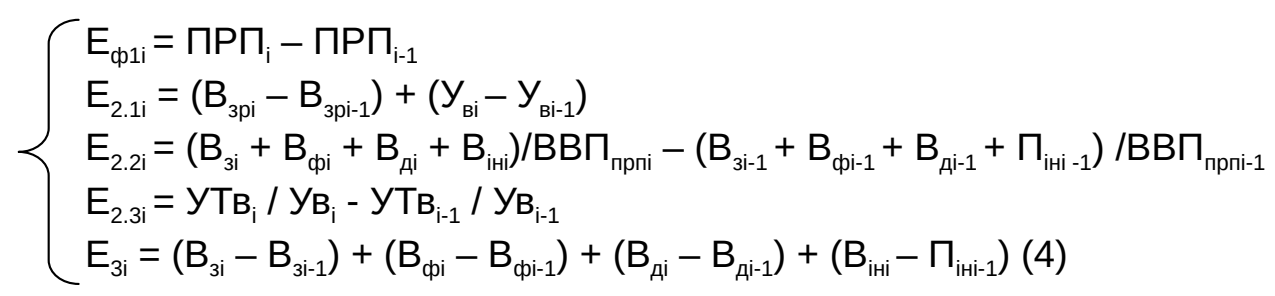

В результаті проведеного аналізу даних за період з 2010 по 2019 рік ми отримали наступні результати, наведені у табл. 2.

3 метою інтерпретації отриманих даних, нами було розроблено умови досягнення екологічної ефрективності податкової політики [6], які було деталізовано за рахунок введення додаткового показника $\mathrm{E}_{2.3 i}$

Умови досягнення екологічної ефективності податкової політики:

1. Податкова політика екологічно ефективна, якщо: $\left\{\mathrm{E}_{\phi 1 \mathrm{i}}>0, \mathrm{E}_{2.1 \mathrm{ii}}<0, \mathrm{E}_{2.2 \mathrm{i}}>0, \mathrm{E}_{2.3 \mathrm{i}}>0, \mathrm{E}_{3 \mathrm{i}}>0\right\}$.

2. Податкова політика екологічно есрективна, але існуюча тенденція до зменшення витрат на здійснення охорони навколишнього природного середовища впливатиме на зменшення екологічної ефрективності податкової політики, якщо: $\left\{\mathrm{E}_{\phi 11}>0, \mathrm{E}_{2.11}<0, \mathrm{E}_{2.21}>0\right.$, $\left.\mathrm{E}_{2.3 \mathrm{i}}>0, \mathrm{E}_{3 \mathrm{i}}<0\right\}$.

3. Податкова політика екологічно ефективна, але існуюча тенденція до зменшення надходжень природно-ресурсних платежів до зведеного бюджету свідчить про зменшення фріскальної ефрективності податкової політики у сорері використання природно-ресурсного потенціалу. Тенденція до зменшення обсягу утилізованих відходів обумовлює необхідність запровадження утилізаційного збору, якщо: $\left\{\mathrm{E}_{\phi 1 \mathrm{i}}<0, \mathrm{E}_{2.1 \mathrm{i}}<0, \mathrm{E}_{2.2 \mathrm{i}}>0, \mathrm{E}_{2.3 \mathrm{i}}>0, \mathrm{E}_{3 \mathrm{i}}>0\right\}$ або $\left\{\mathrm{E}_{\phi 1 \mathrm{i}}<0, \mathrm{E}_{2.1 \mathrm{i}}<0, \mathrm{E}_{2.2 \mathrm{i}}>0, \mathrm{E}_{2.3 \mathrm{i}}<0, \mathrm{E}_{3 \mathrm{i}}>0\right\}$.

4. Податкова політика фріскально та екологічно едективна, але політика держави щодо поводження з відходами негативна, що з часом призведе до погіршення екологічних проблем (наявність даної проблеми обумовлює необхідність запровадження утилізаційного збору), якщо: $\left\{\mathrm{E}_{\phi 1 \mathrm{i}}>0, \mathrm{E}_{2.1 \mathrm{i}}<0, \mathrm{E}_{2.2 \mathrm{i}}>0, \mathrm{E}_{2.3 \mathrm{i}}<0, \mathrm{E}_{3 \mathrm{i}}>0\right\}$.

5. Податкова політика фріскально ефективна, відбувається зменшення викидів забруднюючих речовин, але рівень екологічної безпеки зменшується та політика держави щодо поводження з відходами негативна, що з часом призведе до погіршення екологічних проблем. Наявність даних недоліків обумовлює необхідність запровадження утилізаційного збору та стимулювання суб'єктів госпо- 
Таблиця 2

Показники екологічної ефективності податкової політики України, 2010-2019 рр. [4; 5]

\begin{tabular}{|c|c|c|c|c|c|c|c|c|c|c|}
\hline Показники & $\mathbf{2 0 1 0}$ & $\mathbf{2 0 1 1}$ & $\mathbf{2 0 1 2}$ & $\mathbf{2 0 1 3}$ & $\mathbf{2 0 1 4}$ & $\mathbf{2 0 1 5}$ & $\mathbf{2 0 1 6}$ & $\mathbf{2 0 1 7}$ & $\mathbf{2 0 1 8}$ & $\mathbf{2 0 1 9}$ \\
\hline $\mathrm{E}_{\mathrm{\phi} 1 \mathrm{i}}$ & 4882 & 9397 & -98 & 6606 & 5952 & 22311 & 8193 & $\mathbf{7 2 9 6}$ & 114 & 8624 \\
\hline $\mathrm{E}_{2.1 \mathrm{i}}$ & 14 & 38 & -4 & $-1,85$ & -130 & -76 & -28 & 43 & -12 & - \\
\hline $\mathrm{E}_{2.2 \mathrm{i}}$ & $-0,01$ & 0,03 & 0,08 & $-0,05$ & $-0,05$ & 0,06 & 0,02 & $-0,02$ & $-0,03$ & 0,05 \\
\hline $\mathrm{E}_{2.3 \mathrm{i}}$ & -33 & 0,12 & -3 & 0,01 & $-1,06$ & $-1,17$ & $-1,01$ & $-1,27$ & 2,09 & - \\
\hline $\mathrm{E}_{3 \mathrm{i}}$ & 334 & 1018 & 1407 & 296 & -2112 & 1440 & 1333 & 1094 & 893 & 1489 \\
\hline
\end{tabular}

дарювання впроваджувати новітні ресурсозберігаючі та екологічно чисті технології якщо: $\left\{\mathrm{E}_{\phi 1 \mathrm{i}}>0, \mathrm{E}_{2.1 \mathrm{i}}<0, \mathrm{E}_{2.2 \mathrm{i}}<0, \mathrm{E}_{2.3 \mathrm{i}}<0, \mathrm{E}_{3 \mathrm{i}}>0\right\}$ або $\left\{\mathrm{E}_{\phi 1 \mathrm{i}}>0, \mathrm{E}_{2.1 \mathrm{i}}<0, \mathrm{E}_{2.2 \mathrm{i}}<0, \mathrm{E}_{2.3 \mathrm{i}}<0, \mathrm{E}_{3 \mathrm{i}}<0\right\}$.

6. Податкова політика фріскально спрямована, але обсягів екологічних платежів, що спрямовуються на природоохоронну діяльність недостатньо, політика держави щодо податкового стимулювання запровадження екологічно спрямованих видів діяльності недостатня, якщо: $\left\{\mathrm{E}_{\phi 1 \mathrm{i}}>0, \mathrm{E}_{2.1 \mathrm{i}}>0, \mathrm{E}_{2.2 \mathrm{i}}>0, \mathrm{E}_{2.3 \mathrm{i}}>0, \mathrm{E}_{3 \mathrm{i}}>0\right\}$.

7. Податкова політика екологічно неефективна, але фріскально спрямована, якщо: $\left\{\mathrm{E}_{\phi 1 \mathrm{i}}>0, \mathrm{E}_{2.1 \mathrm{i}}>0, \mathrm{E}_{2.2 \mathrm{i}}<0, \mathrm{E}_{2.3 \mathrm{ij}}<0, \mathrm{E}_{3 \mathrm{i}}>0\right\}$ або $\left\{\mathrm{E}_{\mathrm{\phi} 1 \mathrm{i}}>0, \mathrm{E}_{2.1 \mathrm{i}}<0, \mathrm{E}_{2.2 \mathrm{i}}<0, \mathrm{E}_{2.3 \mathrm{i}}<0, \mathrm{E}_{3 \mathrm{i}}>0\right\}$ або $\left\{\mathrm{E}_{\mathrm{c} 1 \mathrm{i}}>0, \mathrm{E}_{2.1 \mathrm{i}}>0, \mathrm{E}_{2.2 \mathrm{i}}<0, \mathrm{E}_{2.3 \mathrm{i}}>0, \mathrm{E}_{3 \mathrm{i}}>0\right\}$ або $\left\{\mathrm{E}_{\mathrm{cpii}}>0, \mathrm{E}_{2.1 \mathrm{i}}<0, \mathrm{E}_{2.2 \mathrm{i}}<0, \mathrm{E}_{2.3 \mathrm{i}}>0, \mathrm{E}_{3 \mathrm{i}}>0\right\}$.

8. Податкова політика екологічно та фріскально неефективна, якщо: $\left\{\mathrm{E}_{\phi 1 \mathrm{i}}<0, \mathrm{E}_{2.1 \mathrm{i}}>0\right.$, $\left.\mathrm{E}_{2.2 \mathrm{i}}<0, \mathrm{E}_{2.3 \mathrm{i}}<0, \mathrm{E}_{3 \mathrm{i}}<0\right\}$ або $\left\{\mathrm{E}_{\mathrm{\phi p1i}}<0, \mathrm{E}_{2.1 \mathrm{i}}<0\right.$, $\left.\mathrm{E}_{2.2 \mathrm{i}}<0, \mathrm{E}_{2.3 \mathrm{i}}<0, \mathrm{E}_{3 \mathrm{i}}<0\right\}$ або $\left\{\mathrm{E}_{\phi 1 \mathrm{i}}<0, \mathrm{E}_{2.1 \mathrm{i}}>0\right.$, $\left.\mathrm{E}_{2.2 \mathrm{i}}<0, \mathrm{E}_{2.3 \mathrm{i}}>0, \mathrm{E}_{3 \mathrm{i}}<0\right\}$ або $\left\{\mathrm{E}_{\phi 1 \mathrm{i}}>0, \mathrm{E}_{2.1 \mathrm{i}}>0\right.$, $\left.\mathrm{E}_{2.2 \mathrm{i}}<0, \mathrm{E}_{2.3 \mathrm{i}}<0, \mathrm{E}_{3 \mathrm{i}}<0\right\}$.

За допомогою логічних фрункцій програми Excel за заданими нами умовами здійснено оцінювання екологічної ефрективності податкової політики України, що наведено у табл. 3.

В результаті проведеного аналізу виявлено, що у жодному році з досліджуваного періоду податкова політика не була екологічно ефективна. Протягом більшої кількості років податкова політика була фріскально спрямована і лише у 2012 р. та 2015-2016 рр. податкова політика була екологічно ефективна за деякими з встановлених критеріїв.

Проведений аналіз надав змогу виявити наступні суттєві недоліки, які потребують невідкладного вирішення з метою підвищення екологічної есрективності податкової політики та подальшої екологізації податкової системи України:

- недостатні надходження природноресурсних платежів через необґрунтовані ставки та інші елементи податків;
- відсутність утилізаційного збору;

- незначний рівень екологічної безпеки країни, який пов'язано з наявністю екологічно небезпечних видів діяльності суб'єктів господарювання;

-відсутність податкових стимулів у суб'єктів господарювання щодо запровадження екологічно спрямованих видів діяльності;

- незначне фрінансування заходів з охорони навколишнього природного середовища та відтворення природно-ресурсного потенціалу.

Висновки. Проведений аналіз екологічної есрективності податкової політики України та окреслені державою напрями політики екологізації, надали змогу розробити наступні кроки щодо подальшої екологізації податкової політики України:

1) внесення змін до податкового та бюджетного законодавства щодо елементів природно-ресурсних платежів та порядку їх розподілу між Державним та місцевими бюджетами країни;

2) заохочення ресурсозбереження, енергозбереження та зменшення негативного впливу на навколишнє природне середовище через запровадження системи податкових пільг;

3) фрінансування заходів з розробки технологій щодо переробки та утилізації відходів за рахунок розроблення та запровадження утилізаційного збору (сутність та механізм запровадження утилізаційного збору викладено у попередніх наукових публікаціях [7]);

4) подальше впровадження змін у сорері екологічного оподаткування в межах екоподаткової реформи, що передбачає зменшення податків на працю, капітал з одночасним збільшенням екологічних податків;

5) збільшення фрінансування заходів з охорони навколишнього природного середовища та відтворення природних ресурсів за рахунок цільового використання надходжень від природно-ресурсних платежів. 
Таблиця 3

Оцінювання екологічної ефективності податкової політики Україні, 2010-2018 рр.

\begin{tabular}{|c|c|}
\hline Оцінка екологічної ефективності податкової політики України & Роки \\
\hline Податкова політика екологічно ефективна. & - \\
\hline $\begin{array}{l}\text { Податкова політика екологічно ефективна, але існуюча тенденція до зменшення } \\
\text { витрат на здійснення охорони навколишнього природного середовища впливатиме } \\
\text { на зменшення екологічної ефективності податкової політики. }\end{array}$ & - \\
\hline $\begin{array}{l}\text { Податкова політика екологічно ефективна, але існуюча тенденція до зменшення } \\
\text { надходжень природно-ресурсних платежів до зведеного бюджету свідчить } \\
\text { про зменшення фріскальної едективності податкової політики у сфрері використання } \\
\text { природно-ресурсного потенціалу. Тенденція до зменшення обсягу утилізованих } \\
\text { відходів обумовлює необхідність запровадження утилізаційного збору. }\end{array}$ & 2012 \\
\hline $\begin{array}{l}\text { Податкова система фріскально та екологічно ефективна, але політика держави } \\
\text { щодо поводження з відходами негативна, що з часом призведе до погіршення } \\
\text { екологічних проблем. Наявність даної проблеми обумовлює необхідність } \\
\text { запровадження утилізаційного збору. }\end{array}$ & $\begin{array}{l}2015 \\
2016\end{array}$ \\
\hline $\begin{array}{l}\text { Податкова політика фріскально едрективна, відбувається зменшення викидів } \\
\text { забруднюючих речовин, але рівень екологічної безпеки зменшується та політика } \\
\text { держави щодо поводження з відходами негативна, що з часом призведе до } \\
\text { погіршення екологічних проблем. Наявність даних недоліків обумовлює необхідність } \\
\text { запровадження утилізаційного збору та стимулювання суб'єктів господарювання } \\
\text { впроваджувати новітні ресурсозберігаючі та екологічно чисті технолоіії. }\end{array}$ & 2014 \\
\hline $\begin{array}{l}\text { Податкова політика фріскально спрямована, але обсягів екологічних платежів, } \\
\text { що спрямовуються на природоохоронну діяльність недостатньо, політика держави } \\
\text { щодо податкового стимулювання запровадження екологічно спрямованих видів } \\
\text { діяльності недостатня. }\end{array}$ & 2011 \\
\hline Податкова політика екологічно неефективна, але фріскально спрямована. & $\begin{array}{l}2010 \\
2013 \\
2017 \\
2018\end{array}$ \\
\hline а попітика екопог & \\
\hline
\end{tabular}

\section{СПИСОК ВИКОРИСТАНИХ ДЖЕРЕЛ:}

1. Крутякова В.І., Харічков С.К. Екологізація як складова стратегії переходу України до сталого розвитку. URL: https://scholar.google.com/scholar?cluster=5987746963125314178\&hl=ru\&as_sdt=0,5\&scio (дата звернення: 15.11.2020).

2. Маркевич К. «Зелені» інвестиції у сталому розвитку: світовий досвід та український контекст. Центр Разумкова, 2019. 316 с.

3. Hsu, A., L.A. Johnson, and A. Lloyd. Measuring Progress: A Practical Guide From the Developers of the Environmental Performance Index (EPI) / A. Hsu, L. Johnson, A. Lloyd // New Haven: Yale Center for Environmental Law \& Policy. URL: https://web.archive.org/web/20131226110627/http://www.epi.yale.edu/sites/default/files/ downloads/YCELP_Measuring_Progress_Manual.pdf (дата звернення: 15.11.2020).

4. Ооріційний сайт Державної служби статистики України. URL: http://www.ukrstat.gov.ua/ (дата звернення: 18.11.2020).

5. Офіційний сайт Державної казначейської служби України. URL: http://treasury.gov.ua (дата звернення: 18.11.2020).

6. Мартинюк І.В. Екологічна ефрективність податкової політики у сфрері використання та охорони природноресурсного потенціалу. Вісник Чернівецького торговельно-економічного інституту : Економічні науки. 2013. № 4(52). С. 273-278.

7. Мартинюк І.В., Дубовик О.Ю. Утилізаційний збір для неекологічних товарів. АгроСвіт : ТОВ „ДКС Центр”, 2014. № 8. C. 37-42.

\section{REFERENCES:}

1. Krutyakova, V.I., Kharichkov, S.K. "Greening as a component of Ukraine's transition strategy to sustainable development". Available at: https://scholar.google.com/scholar?cluster=5987746963125314178\&hl=ru\&as_ $s d t=0,5 \& s c i o$ (accessed 15 November 2020). 
2. Markevych, K. (2019) «Zeleni» investytsii u stalomu rozvytku: svitovyj dosvid ta ukrains'kyj kontekst ["Green" investments in sustainable development: world experience and Ukrainian context]. Tsentr Razumkova.

3. Hsu, A., Johnson, L., Lloyd, A. "Measuring Progress: A Practical Guide From the Developers of the Environmental Performance Index (EPI)", New Haven: Yale Center for Environmental Law \& Policy. Available at: https://web.archive.org/web/20131226110627/http://www.epi.yale.edu/sites/default/files/downloads/YCELP_Measuring_Progress_Manual.pdf (accessed 15 November 2020).

4. The official site of the State Statistics Service of Ukraine (2020). Available at: http://www.ukrstat.gov.ua (accessed 18 November 2020).

5. The official site of State Treasury Service of Ukraine (2020) "Report on the State Budget of Ukraine 2010-2019". Available at: http://treasury.gov.ua/main/uk/doccatalog/list?currDir=18563 (accessed 18 November 2020).

6. Martyniuk, I.V. (2013) "Environmental efficiency of tax policy in the field of use and protection of natural resource potential". Visnyk Chernivets'koho torhovel'no-ekonomichnoho instytutu: Ekonomichni nauky, vol. 4(52), pp. 273-278.

7. Martyniuk, I.V. (2014) “Disposal fee for non-environmental goods”. AhroSvit: TOV „DKS Tsentr”, vol. 8, pp. 37-42. 